\title{
A TRIANONI BÉKE MEGALKOTÁSA
}

\section{THE MAKING OF THE TREATY OF TRIANON}

\author{
Zeidler Miklós \\ egyetemi docens, Ë̈tvös Loránd Tudományegyetem, Budapest \\ zeidler.miklos@btk.elte.hu
}

\begin{abstract}
ÖSSZEFOGLALÁS
Magyarországon az első világháborús összeomlás után hatalomra jutó kormányok egyöntetűen elfogadták a nemzeti önrendelkezés elvét, de egyikük sem mondott le automatikusan a területi integritás megőrzéséről. A szomszédos országok a nemzeti függetlenség programjával léptek fel, de - Ausztriát leszámítva - az etnikai határokon jóval túlnyúló területeket is követeltek gazdasági és katonai megfontolásokból, s ezzel egyidejűleg Magyarország nagyobb részét katonai megszállás alá vonták. Magyarország csak 1919 végén kapott lehetőséget arra, hogy elküldje képviselőit a párizsi békekonferenciára, amikor a legfontosabb döntések lényegében már megszülettek. A magyar kormány a területi kérdésben a népszavazáson, az etnikai elven, illetve az etnikai-gazdasági-katonai megfontolásokon alapuló megoldásokat is felvetett. A nagyhatalmak azonban ezeket és a legtöbb egyéb magyar javaslatot is elvetették, s csak minimális változásokat hajtottak végre az eredeti békefeltételeken.
\end{abstract}

\section{ABSTRACT}

Following the collapse in World War I, Hungarian governments unanimously accepted the principle of national self-determination, however, none of them automatically abandoned the idea of maintaining territorial integrity. Hungary's neighbours put forward their programmes of national independence but - with the exception of Austria - they claimed territories way beyond their ethnic borders to meet economic and military considerations while bringing the greater part of Hungary under military occupation. It was not until the end of 1919 that Hungary was allowed to send its delegates to the Paris Peace Conference by the time most important decisions had already been made. Concerning territorial questions, the Hungarian Government proposed several solutions based on plebiscites, on the ethnic principle, and on the combination of ethnic, economic and military considerations. The great powers, however, dismissed these as well as most other Hungarian proposals allowing only minor modifications in the original peace conditions.

Kulcsszavak: forradalom, proletárdiktatúra, nemzetiségi kérdés, háborús hadicélok, nagyhatalmak, békeszerződés, Trianon, diplomáciatörténet

Keywords: revolution, proletarian dictatorship, nationality question, war aims, great powers, peace treaty, Trianon, diplomatic history 
A központi hatalmak 1918 őszén - a katonai összeomlás idején - szinte varázsütésre wilsonistává váltak, $\mathrm{s}$ az önrendelkezés eszméje, valamint az annexiók nélküli, méltányos békeszerződések híveinek mutatták magukat. Ennek oka természetesen nem valamiféle világnézeti fordulat volt, hanem annak felismerése, hogy a francia és brit követelésekhez képest, amelyek a legyőzött államok szigorú felelősségre vonására épültek, Woodrow Wilson amerikai elnök békeprogramja - az 1918. januári „14 pont”, a februári „négy alapelv”, a júliusi „négy célkitüzés” és a szeptemberi „öt részlet” - kimondottan elönyösnek tűnt. Ezek ugyanis az egyetemes igazságot, a népek és nemzetek érdekeinek kölcsönös és méltányos tekintetbevételét, valamint a nemzetközi együttmüködést kívánták megtenni a háború utáni politikai rendezés alapjául.

Ám időközben az amerikai álláspont is változott, s immár Washington is elismerte a Monarchia népeinek önálló államaik megalakításához való jogát. Ahogyan Robert Lansing külügyminiszter fogalmazott a Bécsnek címzett október 19-i táviratában: „Az elnök [...] nincs már abban a helyzetben, hogy e népek puszta »autonómiáját« ismerje el a béke alapjának, s ragaszkodnia kell ahhoz, hogy helyette ők maguk döntsék el, az osztrák-magyar kormány milyen lépései egyeztethetők össze törekvéseikkel, valamint a nemzetek nagy családjának tagjaiként a saját jogaikról és jövőjükről alkotott felfogásukkal.” (PRFRUS, 1933, I., 368.) A világháború végnapjaiban tehát nem volt már olyan győztes nagyhatalom, amely Ausztria és Magyarország csonkítatlan fennmaradásával számolt volna.

Ennek dacára Károlyi Mihály kormánya 1918 őszén mégis arra tett - őszinte, de reménytelen - kísérletet, hogy megőrizze a történelmi Magyarország integritását. Amint Lansingnek címzett november 12-i táviratában megállapította: „igazságtalan lenne ezt az ősi, ezeréves Magyarországot darabokra szaggatni”, s ezt maguk a magyarországi nemzetiségek sem kívánják (Zeidler, 2020, 28-30.). A kormány a nagyhatalmakat a demokratikus reformok megalkotásával és a magyar politikai rendszer nyugati mintára történő átalakításával próbálta meggyőzni arról, hogy Magyarországban többé nem ellenséget, hanem kívánatos partnert kell látniuk. A nemzetiségeket pedig a kisebbségi jogok kiterjesztésével - például a területi és a kulturális autonómia bevezetésével - kívánta az ország határain belül tartani. A Szövetséges és Társult Nagyhatalmak azonban nem mutattak érdeklődést a Károlyi-kormány iránt - nem is voltak hajlandóak hivatalosan elismerni -, miközben felhatalmazást adtak az újjászerveződő csehszlovák, román és délszláv haderőnek Magyarország megszállására. Magyarország jövőjére ettől kezdve két párhuzamos eseménysor gyakorolt meghatározó befolyást: az ország 1918 novemberében kezdődő fokozatos katonai megszállása, illetve az 1919 januárjában összeülő párizsi békekonferencia döntései.

A Magyarországra bevonuló, részben francia és olasz parancsnokság alatt álló csehszlovák, román és jugoszláv haderő hamarosan átvette a közigazgatást - nyíltan megsértve a Károlyi-kormánnyal aláírt belgrádi katonai konvenciót -, nagy- 
arányú rekvirálásba kezdett, és a civil lakossággal is kemény kézzel bánt, ami több mint ezer halálos áldozatot követelt. A magyar kormány mégsem látta célravezetőnek a fegyveres ellenállást, mert azzal - felfogása szerint - végleg eljátszhatta volna a Szövetségesek feltételezett jóindulatát. 1919 márciusában, amikor már az ország területének több mint fele idegen ellenőrzés alatt állt, és a román haderő újabb - immár tisztán magyar lakta - vidékek megszállására kapott engedélyt, az időközben köztársasági elnökké avanzsált Károlyi beismerte antantbarát politikájának kudarcát, és a szociáldemokratákat kérte fel kormányalakításra.

A szocdemek és a kommunisták részvételével megalakuló Forradalmi Kormányzótanács bevezette a proletárdiktatúrát, elkötelezte magát a világforradalom mellett, az antant helyett pedig Szovjet-Oroszországhoz és a nemzetközi munkásmozgalomhoz fordult külső támogatásért. A békekonferenciához intézett március 24-i levelében ugyanakkor Kun Béla külügyi népbiztos leszögezte, hogy „az új magyar köztársaságnak szilárd óhaja, hogy békében éljen minden más nemzettel”, és „kormánya késznek nyilatkozik területi kérdések megtárgyalására a népek önrendelkezési elvének alapján, és a területi integritást kizárólag ezzel összhangban szemléli" (Zeidler, 2020, 72.). A békekonferencia azonban - miután Budapestre küldött missziója eredménytelen maradt - április közepén felhatalmazást adott a román és a csehszlovák hadseregnek az újabb offenzívára és a Magyar Tanácsköztársaság felszámolására.

A tanácskormány ekkor felgyorsította a Vörös Hadsereg szervezését, és önvédelmi háborút hirdetett Magyarország és a szovjet típusú munkásállam védelmében. A kettős motivációtól fütött, jól vezetett magyar haderő kezdetben sikereket ért el, s a május-júniusi ,északi hadjárat” során jórészt magyar többségü, az ipari termelés szempontjából is fontos területeket foglalt vissza, egyúttal kísérletet tett a szovjet Vörös Hadsereggel való érintkezés megteremtésére is. A várt szovjet támogatás azonban elmaradt, $\mathrm{s}$ a békekonferencia júniusi ultimátumai, majd a román haderö júliusi ellentámadása megpecsételték a tanácskormány sorsát. A belső társadalmi bázisát elveszítő proletárdiktatúra katonailag is összeomlott, a román csapatok augusztus első napjaiban Budapestre, majd a Dunántúl északi részére is bevonultak.

Eközben - 1919 májusától - a Szövetségesek közvetett támogatást nyújtottak a proletárdiktatúra hatókörén kívül (Bécsben és Szegeden) müködő magyar ellenforradalmi szervezeteknek, amelyek néhány hónappal a tanácskormány bukása után át is vették a hatalmat. Összel már a győztesek is időszerünek tartották a magyar kormány meghívását a békekonferenciára, hiszen sürgetővé vált az immár egy teljes éve zürzavaros magyarországi állapotok konszolidálása, és egyébként is készen álltak a békefeltételek.

A békekonferencia 1919. január 18-án kezdte meg munkáját Párizsban. A tárgyalásokat két fordulóban tervezték lebonyolítani: előbb a győztes hatalmak egymás között kívántak megállapodni a veszteseknek felkínálandó békefeltételekről, amelyeket azután a legyőzött országokkal való közvetlen egyezteté- 
seken óhajtották végső formába önteni. Az első forduló azonban a napirendre kerülö kérdések - új államok alakulása, a Nemzetek Szövetsége megalakítása, mandátumterületek igazgatása, államhatárok megvonása, katonai leszerelés, nemzetközi jogi, állampolgársági, kisebbségvédelmi, gazdasági és közlekedési kérdések stb. - nagy száma és a győztes hatalmak közötti nézeteltérések miatt oly hosszan elhúzódott, hogy a vesztesekkel való tárgyalásokat már nem tartották meg (MacMillan, 2005, 23.).

Ehelyett csupán tudomásukra hozták a békefeltételeket, s bár a legyőzött országok szóban és írásban is előadhatták ellenjavaslataikat, a békekonferencia ezek többségét elutasította. A német, az osztrák, a bolgár és a magyar békedelegáció így csupán részsikereket érhetett el - például csekély mértékủ határkiigazítást, népszavazás kiírását egyes területek hovatartozásának eldöntésére, a háborús jóvátétel összegének valamelyes csökkentését, az elcsatolt nemzetrészek jogvédelmét. Így járt a török kormány is, amely azonban később - jórészt szívós fegyveres ellenállásának köszönhetően - mégis elérte, hogy a győztesek lemondjanak területi követeléseik egy részéről. Az új lausanne-i béke azonban így is súlyos veszteségeket okozott Törökországnak.

A csehszlovák, a román és a jugoszláv békedelegáció már a konferencia első heteiben - 1919. január 31. és február 18. között - szóban és írásban is előterjesztette területi igényeit az öt nagyhatalom (Brit Birodalom, Egyesült Államok, Franciaország, Japán, Olaszország) vezetőiből álló Legfelsőbb Tanácsnál. Valamennyien arra hivatkoztak, hogy sok évszázados magyar elnyomás alól kívánják felszabadítani nemzetüket. Követeléseik azonban jóval túllépték a hivatalos népszámlálási adatok alapján megrajzolható etnikai határokat. Ezért egyrészt kétségbe vonták a magyar statisztikai hivatal által közölt nemzetiségi (anyanyelvi) adatok hitelességét - s helyettük saját, olykor teljesen önkényes számításokkal álltak elő -, másrészt új argumentumokat hoztak fel az általuk is elismerten magyarlakta területek bekebelezésére. Érvrendszerükben így megjelent:

1. a történeti jogra - vagyis egy adott területen való korai megtelepedésre való hivatkozás (például: a dák-román kontinuitás elmélete, csehszlovák igény a német többségűvé vált Szudéta-vidékre),

2. a honvédelmi érdekek hangsúlyozása (például: jól védhető folyószakaszok, stratégiailag fontos magaslatok birtoklása),

3. a gazdasági életképesség követelménye (például: „létfontosságú” termőterületek, bányák, iparvidékek, vízi és vasúti vonalak megszerzése).

Ami a konkrét követeléseket illeti, Csehszlovákia a szlovák többségű észak-magyarországi területeken kívül túlnyomó többségükben magyarlakta vidékekre - a Csallóközre, a Dunakanyarra, az Északi-középhegység iparosodottabb zónájára - is benyújtotta igényét, ami a Pozsony-Vác-Miskolc-Ung vonaltól északra és nyugatra fekvő területek elcsatolását jelentette volna (az említett városokkal 
együtt). A csehszlovák küldöttség jelezte továbbá, hogy a Tisza és az Ung folyók közötti területen élő magyarországi ruszinok szintén Csehszlovákiához kívánnak csatlakozni. Mindeme területeken összesen mintegy 1,5 millió magyar élt - túlnyomórészt zárt tömbökben, közvetlenül a tervezett határok mentén.

A román kormány az 1916. augusztus 17-én aláírt bukaresti szerződésre alapozta területi igényeit, amelyben a Brit Birodalom, Franciaország, Olaszország és Oroszország háborús győzelem esetére Erdély és a Bánság egészének, valamint a Tiszántúl nagyobb részének átcsatolását ígérte meg Romániának, amennyiben az megtámadja az Osztrák-Magyar Monarchiát. A román követelés így a TiszaVásárosnamény-Debrecen-Gyoma-Szeged-Tisza vonaltól keletre fekvő területekre terjedt ki (Vásárosnaményt igen, a többi várost nem beleértve). E területen 2,3 millió magyar lakott, mintegy fele a tervezett új határok mentén.

A jugoszláv igények Horvát-Szlavónia és a Bánság egészére, a Bácska nagyobb részére, valamint Zala, Somogy és Baranya megye déli sávjára terjedtek ki. Ez a Szentgotthárd-Letenye-Murakeresztúr-Barcs-Siklós-Mohács-Horgos-SzegedMaros vonaltól délre fekvő területeket jelentette (az említett településeket is beleértve), ahol összesen mintegy 700 ezer magyar élt, zömmel a javasolt határok mentén.

A belgrádi és a prágai kormány közös javaslata volt egy észak-déli irányú, 50-60 km szélességủ területsáv („,szláv korridor”) leválasztása Nyugat-Magyarországról (és kisebb részben Ausztriáról), amely összekötötte volna a Szerb-Horvát-Szlovén Királyságot és Csehszlovákiát - közvetett kijáratot biztosítva utóbbinak az Adriai-tengerhez.

A Párizsba csak jóval később meghívott osztrák békedelegáció június 16-án nyújtott be területi igényt Magyarországgal szemben: a határ egész hosszában húzódó, közel $5200 \mathrm{~km}^{2}$ területü, többségében németajkú Burgenlandot követelte népszavazás útján.

A szláv korridor ötletét a békekonferencia rövid úton elvetette, a többi követelés azonban végigjárta a döntéselőkészítő fórumokat, $\mathrm{s}$ végül a Legfelsőbb Tanács elé került, amely - a népszavazást minden esetben mellőzve - északon, keleten és nyugaton $85-90 \%$-ban, délen $75-80 \%$-ban helyt is adott a területi igényeknek. Ezenkívül Lengyelországhoz került néhány kis hegyi falu Árva és Szepes vármegyéből, Olaszország pedig megszerezte Fiumét, jóllehet azt a békekonferencia eredetileg a Szerb-Horvát-Szlovén Királyságnak szánta. A döntések 1919. június-július folyamán születtek meg, de kisebb módosításokra - a magyar-jugoszláv határon - még decemberben is sor került. (Fiume hovatartozásának ügyét csak 1924-ben sikerült lezárni.)

Ha a nagyhatalmak valamennyi fenti követelésnek helyt adtak volna, a Magyar Királyság területének 78\%-át, népességének pedig 70\%-át veszíti el, s az új állam 62 ezer $\mathrm{km}^{2}$-re zsugorodik, mindössze 5,4 milliós népességgel. Ha viszont a békekonferencia tisztán az etnikai elvet érvényesíti - és nem vonja kétségbe a magyarországi népszámlálások nemzetiségi adatainak hitelességét -, akkor az 
új Magyarország területe mintegy 120 ezer $\mathrm{km}^{2}$, lakossága mintegy 10 millió fö lehetett volna. A békeszerzők döntéséből végül egyfajta „kompromisszum” volt kiolvasható: az új határok egy 93 ezer $\mathrm{km}^{2}$-es, az 1910. évi cenzus szerint 7,6 millió lakost számláló Magyarország képét rajzolták ki.

A Magyarországgal szemben támasztott területi követelések, illetve nyereségek a párizsi békekonferencián (az 1910. évi magyarországi népszámlálás adatai alapján)

\begin{tabular}{|c|c|c|c|c|}
\hline \multirow{2}{*}{ Ország } & \multicolumn{2}{|c|}{ Követelés (kerekítve) } & \multicolumn{2}{|c|}{ Nyereség (kerekítve) } \\
\hline & Terület $\left(\mathbf{k m}^{2}\right)$ & Lakosság & Terület $\left(\mathbf{k m}^{2}\right)$ & Lakosság (fó) \\
\hline \multirow[b]{2}{*}{ Csehszlovákia } & 75000 & 4400000 & 62000 & 3600000 \\
\hline & + 4700 település & $\begin{array}{l}39 \% \text { cseh, szlovák } \\
10 \% \text { ruszin } \\
39 \% \text { magyar }\end{array}$ & + 4000 település & $\begin{array}{l}48 \% \text { cseh, szlovák } \\
12 \% \text { ruszin } \\
31 \% \text { magyar }\end{array}$ \\
\hline \multirow{2}{*}{$\begin{array}{l}\text { Lengyel- } \\
\text { ország }\end{array}$} & 3000 & 150000 & 550 & 24000 \\
\hline & + 150 település & $\begin{array}{l}11 \% \text { lengyel } \\
2 \% \text { magyar }\end{array}$ & + 25 település & $\begin{array}{l}61 \% \text { lengyel } \\
1 \% \text { magyar }\end{array}$ \\
\hline \multirow[b]{2}{*}{ Románia } & 122000 & 6500000 & 103000 & 5300000 \\
\hline & +4500 település & $\begin{array}{l}45 \% \text { román } \\
36 \% \text { magyar }\end{array}$ & + 4100 település & $\begin{array}{l}54 \% \text { román } \\
32 \% \text { magyar }\end{array}$ \\
\hline \multirow[b]{2}{*}{ Jugoszlávia } & 43000 & 3100000 & 21000 & 1500000 \\
\hline & + 1800 település & $\begin{array}{l}\text { 24\% délszláv } \\
39 \% \text { magyar }\end{array}$ & + 600 település & $\begin{array}{l}40 \% \text { délszláv } \\
30 \% \text { magyar }\end{array}$ \\
\hline \multirow[b]{2}{*}{ Olaszország } & 21 & 50000 & 21 & 50000 \\
\hline & +1 település & $\begin{array}{l}49 \% \text { olasz } \\
13 \% \text { magyar }\end{array}$ & +1 település & $\begin{array}{l}49 \% \text { olasz } \\
13 \% \text { magyar }\end{array}$ \\
\hline \multirow[b]{2}{*}{ Ausztria } & 5000 & 400000 & 4000 & 290000 \\
\hline & + 370 település & $\begin{array}{l}69 \% \text { német } \\
16 \% \text { magyar }\end{array}$ & + 320 település & $\begin{array}{l}74 \% \text { német } \\
9 \% \text { magyar }\end{array}$ \\
\hline \multirow{2}{*}{ Összes } & 221000 & 12900000 & 190000 & 10700000 \\
\hline & +10 700 település & $39 \%$ magyar & + 9100 település & $30 \%$ magyar \\
\hline \multirow[b]{2}{*}{$\begin{array}{l}\text { Magyar- } \\
\text { országnál } \\
\text { marad }\end{array}$} & 62000 & 5400000 & 93000 & 7600000 \\
\hline & + 1700 település & $\begin{array}{l}90 \% \text { magyar } \\
7 \% \text { német } \\
2 \% \text { szlovák }\end{array}$ & + 3400 település & $\begin{array}{l}88 \% \text { magyar } \\
7 \% \text { német } \\
2 \% \text { szlovák }\end{array}$ \\
\hline $\begin{array}{l}\text { A Magyar } \\
\text { Királyság } \\
\text { 1910-ben }\end{array}$ & $\begin{array}{l}\mathbf{2 8 2} \mathbf{8 7 0} \mathbf{k m}^{\mathbf{2}} \\
+12543 \text { település }\end{array}$ & \multicolumn{3}{|c|}{$\begin{array}{l}18264533 \text { fó } \\
54 \% \text { magyar, } 16 \% \text { román, } 11 \% \text { cseh, szlovák, } \\
10 \% \text { német, } 4 \% \text { délszláv, } 3 \% \text { ruszin }\end{array}$} \\
\hline
\end{tabular}


Magyarországon Teleki Pál és Buday László kezdeményezésére földrajztudósok és statisztikusok már 1918 októberében megkezdték a felkészülést a majdani békekonferenciára. Károlyi Mihály gróf kormánya kezdettől fogva jelentős anyagi támogatást és kellő intézményi hátteret biztosított a munkához, amelybe az év végétől egy frissen megalakult társadalmi szervezet, Magyarország Területi Épségének Védelmi Ligája (röviden: Területvédő Liga) is bekapcsolódott. A kormány 1919. február közepén - egy hónappal a békekonferencia megnyitása után - már ki is jelölte a Párizsba majdan kiküldendő delegáció tagjait, amelynek élén Károlyi állt mint nemrégiben hivatalba lépett köztársasági elnök. A nagyhatalmak azonban egyelöre nem számoltak Magyarország meghívásával, amelynek kormányát hivatalosan el sem ismerték.

Nem kapott lehetőséget a békekonferencián való részvételre az 1919 márciusában hatalomra jutott tanácskormány sem. Május első felében rövid időre felmerült ugyan a meghívás lehetősége, a nagyhatalmak azonban - amelyek kezdettől fogva bizalmatlanul, majd egyre növekvő ellenszenvvel tekintettek a bolsevizmusra - a hónap közepétől már nyíltan ellenségként kezelték a Tanácsköztársaságot, $\mathrm{s}$ annak felszámolására törekedtek. A kommün idején a béke-előkészítés folyamata is lelassult, mivel a munkatársak egy része a háttérbe húzódott, vagy elmenekült a proletárdiktatúra elől. Az 1919 májusában Aradon megalakult, majd Szegedre költöző, Károlyi Gyula vezette ellenkormány - föként annak külügyminisztere, Teleki Pál - megpróbálta ugyan folytatni a béketárgyalásokra szánt magyar anyag összeállítását, ez azonban szakemberek hiányában csekély eredménnyel járt.

A tanácskormány bukását követően azonban, 1919. augusztus 21-én Budapesten megalakult a Béke-előkészítő Bizottság (röviden: Békeiroda), amely egyre gyarapodó létszámmal, a korábbinál jóval szervezettebben folytatta a munkát. Újabb tanulmányok, statisztikák és térképek készültek Magyarország történelméről, földrajzáról, éghajlatáról, természeti kincseiről, politikai berendezkedéséről, nemzetgazdaságáról, közlekedési útvonalairól, felekezeti viszonyairól, az országot benépesítő különböző nemzetiségek területi elhelyezkedéséről, társadalmi integrációjáról, jogi, politikai és gazdasági helyzetéről, műveltségi fokáról. A Békeiroda ekkor már ismerte a szomszédos országok követeléseit és a mögöttük álló érveket, így ezek ellenében célzottan sorakoztathatta fel saját argumentumait. Az 1919. júniusban, szeptemberben, illetve novemberben megkötött német, osztrák és bolgár békeszerződés szövegének összevetéséből pedig kiderült, hogy a békék egy „kaptafára” készülnek, szerkezetük s helyenként a paragrafusok megszövegezése is nagyon hasonló. Ennek alapján a majdani magyar békefeltételek egy részét akár előre meg is lehetett jósolni, annál is inkább, mivel a magyar határokra vonatkozó legfontosabb döntések már 1919 júliusában megszülettek, és Magyarországon is ismertté váltak.

Magyarországot végül december 1-én hívták meg a konferenciára, miután a Friedrich István vezette, az antant által elfogadhatatlannak ítélt ellenforradalmi 
kormány helyébe jobboldali túlsúlyú, de szociáldemokrata és liberális minisztereket is felvonultató koalíciós kormány lépett a keresztényszocialista Huszár Károly vezetésével. E „koncentrációs” kormány november 29-én végre megkapta a győztesek elismerését, s ezzel megnyílt az út Párizsba, a békekonferenciára.

A magyar küldöttség 1920. január 5-én reggel indult útnak, és kétnapi vonatozás után érkezett meg Párizsba. Elnöke Apponyi Albert volt, tagjai között ott volt Teleki Pál és Bethlen István, valamint a századelő és két háború közötti időszak számos befolyásos minisztere és diplomatája. A delegáció a történelmi Magyarország egyfajta lenyomata volt: a küldöttek kivétel nélkül a politikai, diplomáciai, katonai, gazdasági és kulturális elitből rekrutálódtak, világnézetüket jobbára a konzervativizmus - ritkábban a (konzervatív) liberalizmus -, valamint a világháború és a forradalmak hatására megerősödött nacionalizmus határozta meg. A delegációban felülreprezentált volt a (szak)politikailag aktív arisztokrácia és az inkább nemesi, mint polgári háttérrel bíró állami tisztviselőréteg (Zeidler, 2018, 57.).

A küldöttség Párizs nyugati elővárosában, Neuillyben, a Château de Madrid nevü szállodában kapott elhelyezést - teljes panzióval, saját költségen -, ahol elözőleg a bolgár delegáció is lakott. A küldöttek mozgását francia detektívek figyelték, Párizsba pedig még városnézés, vásárlás, színházlátogatás céljából is csak az ő kíséretükben volt szabad beutazni. Az intézkedéssel megpróbálták elejét venni annak, hogy a delegáció politikusokkal, közéleti személyiségekkel, újságírókkal lépjen kapcsolatba, és rajtuk keresztül szerezzen nagyobb nyilvánosságot - esetleg támogatást - a magyar békecéloknak. Ottlik György külpolitikai szakírót, aki január 19-én fel akarta keresni a The Times párizsi tudósítóját, a detektívek feltartóztatták, a békedelegációnak pedig haza kellett küldenie őt Budapestre (Zeidler, 2012, 49., 52-53.).

A magyar békedelegáció 1920. január 14-31. között húsz olyan, ún. elözetes jegyzéket - valamint az ezekhez tartozó terjedelmes mellékleteket - nyújtott be a békekonferenciához, amelyek még a békefeltételek átvétele előtt készültek. Jelentőségénél fogva kiemelkedett közülük a 45 melléklettel ellátott II. sz. Bemutatkozó jegyzék, amely többek között Ausztria és Magyarország közjogi kapcsolatának alakulásáról, továbbá Magyarország földrajzáról, népesedéséről, nemzetiségeiről, nemzetgazdaságáról, oktatáspolitikájáról, a lakosság müveltségi viszonyairól, valamint az ország világháborúban játszott szerepéről közölt adatokat (MB, 1920, 3-17.). Külön jegyzékek foglalkoztak az elcsatolásra szánt területekkel és nemzetiségekkel. Az erdélyi kérdésröl szóló VIII. sz. jegyzék (MB, 1920, 117-133.), a XII. sz. Délvidéki jegyzék (MB, 1920, 362-368.), A ruténkérdésröl szóló XIII. sz. jegyzék (MB, 1920, 406-414.), A tótkérdésről szóló XIV. sz. jegyzék (MB, 1920, 437-445.), a Nyugat-Magyarországról szóló XV. sz. jegyzék (MB, 1920, 455457.), valamint $A$ sokácokról és a bunyevácokról szóló XVI. sz. jegyzék (MB, 1920, 473-474.) is részletes adatokat tartalmazott e vidékek etnikai és gazdasági viszonyairól, Magyarország központi területeivel való régóta fennálló, szoros 
kapcsolatairól és a szomszéd országok igényeinek önkényességéről, rosszhiszemüségéről, s némelyik az idegen megszálló csapatok által elkövetett visszaélésekre, atrocitásokra is kitért.

A magyar küldöttség január 15-én kapta kézhez a békefeltételeket, amelyeknek szigorúsága megrendítő volt, de nem okozott különösebb meglepetést. Másnap Apponyi szóban fejtette ki észrevételeit a Legfelsőbb Tanács tagjai előtt, ahol általános támadást intézett a béketervezet ellen. Megállapította, hogy csekély háborús felelősségéhez képest Magyarországot aránytalanul súlyos, „már a létét is veszélyeztető" büntetéssel sújtják. Kifogásolta az etnikai elv részrehajló alkalmazását, s tagadta, hogy a magyar kormányok elnyomó politikát folytattak volna a nemzetiségekkel szemben. Helytelenítette, hogy az elcsatolandó területek kormányzása olyan nemzetiségek kezébe kerül, amelyek ,jelenleg többnyire alacsonyabb kulturális fokon állanak". Ideális képet festett a történelmi Magyarországról, s biztonságpolitikai és gazdasági érvek egész sorát vonultatta fel az integritás fenntartása mellett. Megállapította, hogy Magyarország évszázadokon át fontos szerepet játszott Közép-Európában ,a béke és a biztonság”, valamint „az egyensúly és a stabilitás” fenntartásában, „biztosítva így Európa békéjét a keletről fenyegető közvetlen veszedelmekkel szemben". Hangsúlyozta, hogy a Kárpát-medence természet adta, szerves geográfiai egysége lehetővé teszi a régió harmonikus gazdasági együttműködését, ennek sikerét azonban csak az egységes kormányzás garantálhatja. S bár elismerte a győztesek jogát a hatalmi erőviszonyok megváltoztatására, a méltányos és tartós béke megteremtését a területek hovatartozásáról döntő népszavazásoktól várta. Ezt nevezte a békedelegáció fő követelésének, s kijelentette: „elöre alávetjük magunkat a népszavazás eredményének, bármi legyen is az" (Zeidler, 2020, 122-129.).

Apponyi beszéde meglepően nagy hatást gyakorolt hallgatóságára, különösen David Lloyd George brit és Francesco Nitti olasz miniszterelnökre, akik februárban a magyar határok újratárgyalását javasolták. Március első napjaiban, a brit, francia és olasz részvétellel - az amerikaiak és a japánok távollétében - lebonyolított londoni ülésszakon csakugyan napirendre is került a magyar határok ügye, ám a francia küldöttek hajthatatlansága miatt végül mégsem foglalkoztak érdemben a kérdéssel. Mindössze abban állapodtak meg, hogy az esetleges kisebb módosításokra majd a határvonal végleges kijelölését végző szakértői bizottságok tehetnek javaslatot (Romsics, 2001, 183-189.).

Eközben a magyar békedelegáció több új javaslattal is elöállt a határkérdésben, s az Apponyi által említett népszavazások mint fő követelés mellett konkrétabb területi megoldásokat is felvetett. A január 18-án átadott X. sz. jegyzék például bemutatta a közvetlenül a tervezett határok mentén élő, elcsatolásra szánt magyarok által lakott területek pontos elhelyezkedését, ezzel mintegy ötletet adva a békekonferenciának, hol is kellene kezdenie a határok módosítását (MB, 1920, 293-298.). A „C” kísérőjegyzék pedig - amely lényegében a február 12. és már- 
cius 10. között beadott 18 ún. válaszjegyzék bevezetője volt - már felvetette a Székelyföld visszacsatolásának lehetőségét is, amelyet, úgymond, „könnyü volna a magyar középponttal összekötni egy vegyesnyelvủ folyosó által" (MB, 1921, 5.).

Március második felében, amikor a londoni tárgyalásokról érkező kedvezőtlen hírek eljutottak Neuillybe, nyilvánvalóvá vált, hogy a békekonferencia elutasítja a magyar javaslatokat, és nem fogja jelentősen módosítani a békefeltételeket. A delegáció ekkor alaposan megvizsgálta azt a kérdést, milyen reakciókat válthat ki, ha Magyarország nem írja alá a békeszerződést. A március 23-24-én tartott tanácskozáson a felszólalók úgy vélték, hogy a győztes hatalmak a magyar ellenállás esetén gazdasági blokádot, sőt esetleg újabb katonai megszállást vezetnek majd be, s ezek már rövid távon is nagymértékben rontanák a magyarországi közállapotokat, így a kormány mégiscsak a béke aláíására kényszerülne - esetleg még rosszabb feltételekkel. Bethlen István szerint az aláírás megtagadása esetén tovább romlana a megszállt területeken élő magyar lakosság helyzete, fokozódna üldöztetésük, s tömegével kényszerülnének kivándorolni. Ez még jobban megterhelné a magyar gazdaságot - $\mathrm{s}$ félö, hogy Magyarország esetleg örökre elveszíti a megszállt területeket. A küldöttek többsége végül egyetértett azzal, hogy az adott kényszerhelyzetben elkerülhetetlen a béke elfogadása (Zeidler, 2018, 34-38.).

Ezekben a napokban azonban - váratlan fordulattal - titkos tárgyalások kezdődtek Párizsban a francia és a magyar kormány képviselőinek részvételével, amelynek tárgya jelentős francia tőkebefektetések eszközlése, valamint a két ország külpolitikájának összehangolása volt. (A tárgyalások valóban titkosan folytak, azokról - elvileg - még a békedelegáció tagjai közül is csak kevesen tudtak.) A gazdasági krízishelyzetben lévő, külpolitikailag elszigetelt, süllyedőben lévő Magyarországnak igazi mentőöv lett volna ez az együttműködés, Franciaországnak pedig - amelyik éppen kelet-közép-európai szövetségi rendszerének kiépítésén dolgozott - gazdasági és politikai szempontból is előnyös lett volna, ha a Duna-medence fő vízi és vasúti közlekedési vonalait birtokló Magyarországot is be tudja vonni partnerei közé. Az ilyen jellegű francia-magyar közeledés azonban sok érdeket sértett - a tárgyalások nem véletlenül folytak titokban -, s amikor május folyamán kiszivárogtak a tárgyalások részletei, az ügy Magyarországon és külföldön is nagy felháborodást keltett. London és Róma saját befolyásszerzési törekvéseit, Prága, Bukarest és Belgrád pedig friss területi nyereségeit látta veszélyeztetve - $\mathrm{s}$ valamennyien árulással vádolták Párizst, amely szövetségeseivel szemben az ellenséges Magyarországot részesíti előnyben. A magyar közvélemény is nehezen fogadta el, hogy a kormány hirtelen az addig fő ellenségnek tekintett franciákkal barátkozik, s ezzel, úgymond, nem csupán a nemzeti büszkeséget sérti meg, hanem hosszú távra alárendeli az országot idegen érdekeknek. A tárgyalások egy időre mindenesetre feltámasztották a magyar kormány optimizmusát, és 1920 áprilisában újabb határjavaslat készült Teleki Pál „műhelyében”, amely a nemzetiségi és a gazdasági szem- 
pontok kombinálásával, valamint egyes régiókban népszavazás alkalmazásával hosszú távra meghatározta a revízióval kapcsolatos magyar tervezgetéseket (Ormos, 1975; Zeidler, 2012, 62-67.).

A francia-magyar tárgyalások nem okoztak fennakadást a békekonferencia működésében, így május elejére elkészült a magyar békeszerződés végleges szövege. Ezt, valamint a magyar békejegyzékekre adott tételes választ, továbbá a magyar észrevételek elutasítását általánosságban megindokoló, Alexandre Millerand francia kormányfö, a békekonferencia elnöke által aláírt kísérőlevelet május 5-én vette át Praznovszky Iván, a delegáció főtitkára, aki azonnal Budapestre utazott a dokumentációval.

Az anyagból kiderült, hogy a nagyhatalmak csak néhány kevésbé jelentős kérdésben adtak helyt a magyar delegáció észrevételeinek. A békeszerződés szövege összesen 56 ponton tért el az előzetes békefeltételekben foglaltaktól (MB, 1921, 516-521.). A módosítások azonban nem érintették a szerződés lényegét, jobbára csak stiláris vagy jogtechnikai jellegü pontosításokat jelentettek. Egyes kérdésekben azonban - a hadianyaggyártás korlátozása, a jóvátétel összegének megállapítása, a Bécsben őrzött magyar mükincsek tulajdonjoga, az elcsatolt területekről Magyarországra költözők vagyona, a Duna-medence egységes árvízvédelmi rendszere - valóban észszerübb, illetve nagyvonalúbb szabályokat rögzítettek. Annak pedig, hogy a szomszéd országok kisebbségvédelmi kötelezettségeit a magyar béke szövegébe is beiktatták, nemzetközi jogi szempontból nagy jelentősége volt, hiszen így Magyarország is szerződő féllé vált és felléphetett a szerződés végrehajtása érdekében.

A Minisztertanács május 13-i és 17-i ülésén foglalkozott a békeszerződés kérdésével, $\mathrm{s}$ végül az aláírás mellett döntött - lényegében ugyanazon szempontok alapján, amelyeket már a békedelegáció márciusi értekezletén is felmerültek. A békedelegáció formálisan lemondott, az aláírás feladata így a kormányra szállt, amely - az általános elkeseredettség és a tiltakozó tüntetések ellenére - a hónap végén kijelölte a békeszerződés aláiróit Benárd Ágost népjóléti és munkaügyi miniszter, valamint Drasche-Lázár Alfréd külügyi államtitkár személyében. (Utóbbi diplomataként rendkívüli követ és meghatalmazotti miniszter rangot viselt, s így formailag megfelelt a békekonferencia elvárásainak, hogy Magyarország részéről két miniszter írja alá a békeokmányt.)

A békeszerződés aláírására 1920. június 4-én délután került sor a versailles-i kastélykertben lévő Nagy-Trianon palotában. „Mikor a magyar küldötteket bejelentették, mindenki felállt, azután a két magyar fömegbízott elfoglalta kijelölt helyét a patkó alakú asztalnál, szemben a portugáli küldöttekkel. Ekkor Millerand elnök felszólította őket, hogy a megállapított szerződést írják alá. Elsőnek dr. Benárd írta alá, egy külön erre a célra a terem közepén felállított asztalon. Ezután következett a szövetséges 5 nagyhatalom, majd a többi állam, a francia betürend szerinti sorban. Miután Millerand elnök az ülést berekesztette, a magyar megbí- 
zottak elsőnek hagyták el az emlékezetes trianoni kastélyt" - áll a békedelegáció hivatalos jelentésében (MB, 1921, VIII.).

A magyar közvéleményben kezdettől meghatározó volt, s ma is széles körben tovább él az a meggyőződés, hogy a békeszerződés afféle tákolmány: téves információkon és gonosz szándékokon nyugvó jogi fércmü. Ezt a minősítést az elkeseredés és a felháborodás szülte, amit a szerződés legismertebb és magyar részről leginkább sérelmezett, az ország új határairól és részleges leszereléséről intézkedő fejezetei váltottak ki. E cikkelyek azonban a dokumentumnak csupán a töredékét teszik ki, miközben az egész szerződés jogi szempontból nagyon is körültekintően összeállított, általános kérdésekre és apró részletekre is kiterjedő mü, mely azonban - kétségtelenül - egyoldalúan érvényesíti a győztesek politikai érdekeit, s teljesen figyelmen kívül hagyja a magyar szempontokat. A közkeletủ szóhasználat ezért Magyarországon, csakúgy, mint a többi vesztes államban, diktátumnak bélyegezte a dokumentumot, annak ellenére, hogy az - természetesen - „békeszerződés” néven került be a Magyar Törvénytárba mint az 1921. évi XXXIII. törvénycikk.

A béke súlyos rendelkezései politikai, anyagi és morális szempontból is erősen megterhelték a magyar társadalmat, ezért a két háború közötti időszakban a magyar kormány fő külpolitikai célkitüzése - a közvéleménnyel egyetértésben - a békeszerződés revíziója volt.

\section{IRODALOM}

MacMillan, M. (2005): Béketeremtők. Az 1919-es párizsi békekonferencia. (ford. Barna J.) Budapest: Gabo Kiadó

MB (1920): A magyar béketárgyalások. Jelentés a magyar békeküldöttség müködéséröl Neuilly s/S.-ben 1920 januárius-március havában. I. köt. Budapest: M. kir. Külügyminisztérium, https://adtplus.arcanum.hu/hu/view/BMEKonyvek_TarsadalomtudomanyiKonyvtar 2965190/?query=magyar\%20b\%C3\%A9ket\%C3\%A1rgyal\%C3\%A1sok\&pg=92\&layout=s

MB (1921): A magyar béketárgyalások. Jelentés a magyar békeküldöttség müködéséröl Neuilly s/S.-ben 1920 januárius-március havában. II. köt. Budapest: M. kir. Külügyminisztérium

Ormos M. (1975): Francia-magyar tárgyalások 1920-ban. Századok, 109, 5-6, 904-949.

PRFRUS (1933): Papers Relating to the Foreign Relations of the United States. 1918. Supplement 1. The World War. Vol. I-II. Washington: United States Government Printing Office (Vol I: https://history.state.gov/historicaldocuments/frus1918Supp01v01)

Romsics I. (2001): A trianoni békeszerződés. Budapest: Osiris Kiadó

Zeidler M. (szerk.) (2012): A Monarchiától Trianonig egy magyar diplomata szemével. Praznovszky Iván emlékezései. (vál., bev. tan., jegyz. Zeidler M.) Budapest: Olvasó Sarok Kiadó

Zeidler M. (szerk.) (2018): A magyar békeküldöttség naplója. Neuilly-Versailles-Budapest. (vál., ford., bev. tan., jegyz. Zeidler M.) 2., jav. kiad. Budapest: MTA BTK Történettudományi Intézet

Zeidler M. (szerk.) (2020): Trianon. 3., jav. kiad. Budapest: Osiris Kiadó 